\title{
Perceptive Farmers Viewed from Knowledge and Skills in Utilizing Beef cattleFeces into Organic Solid Fertilizer
}

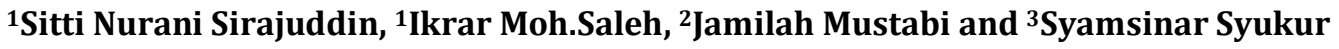

${ }^{1}$ Department of Socio-Economic, Faculty of Animal Science Hasanuddin University

${ }^{2}$ Department of Nutrition and Feed Livestock, Faculty of Animal Science Hasanuddin University

${ }^{3}$ Department of Agribusiness, Faculty of Agriculture, Islamic University of Makassar

Correspondence Author: Sitti Nurani Sirajuddin, Department of Socio-Economic, Faculty of Animal Science Hasanuddin University E-mail: sitti.nurani@unhas.ac.id

Received date: 11 April 2018, Accepted date: 15 May 2018, Online date: 25 May 2018

Copyright: (C) 2018 Sitti Nurani Sirajuddin et al. This is an open-access article distributed under the terms of the Creative Commons Attribution License, which permits unrestricted use, distribution, and reproduction in any medium, provided the original author and source are cre dited.

\begin{abstract}
Waste is the waste material from a process of activity which still has economic valueso it is necessary to do the processing that can increase the income of farmers. This study aims to determine the perception of farmers in processing cow feces into solid fertilizer in terms of knowledge and skills of farmers. The research was conducted in March 2018 until April 2018 . This research was conducted in Patampanua Village, Marioriawa Subdistrict, Soppeng Regency. The type of research used is descriptive quantitative. This research uses survey method. The type of data used in this study is qualitative data and quantitative data. Data sources are primary data and secondary data. The population in this research is the whole breeder of beef cattle in Patampanua Village, MarioriawaSubdistrict, Soppeng Regency. The number of population in this research is 78 breeders of beef cattle and all population taken as sample of research. The data collection techniques used in this study are observation and interview. Data analysis used in this research is descriptive statistic. The result of research Farmers are less aware of the types and materials and processing of organic fertilizer and not yet skilled in the utilization of organic fertilizer.
\end{abstract}

Key words: organic solid, waste, feces, farmers, beef cattle

\section{INTRODUCTION}

The development of livestock sub-sector in Indonesia needs to be improved, considering that demand for livestock products in Indonesia generally tends to increase from year to year. This is in line with the increased awareness of the nutritional needs of the community, but not balanced by the increase in livestock population. Livestock as one of the agricultural sub-sector was an integral part of the success of the sector in Indonesia. The vision of agricultural development was a cultured livestock industry by industrial base. Livestock development as an integral part of agricultural development contributes to the fulfillment of animal protein to increase the consumption of animal protein for the community $[1,2]$.

Paradigm farm development was the realization of a healthy society and productive and creative through atough farm based on local resources [3, 4]. Beef cattle are one of the livestock that can be relied upon as a provider of meat. This is a very profitable for breeders if they can take advantage of this opportunity well. In addition, the fulfillment of animal protein can increase the nutritional needs of people to improve intelligence [5]. Barriers or problems in the livestock business among them are the problem of fecal waste produced by beef cattle ranging from 10-30 kg / head / day [6]. Waste is inorganic or inorganic material that is not utilized anymore, so it can cause serious problems for the environment if not handled properly. Waste can be derived from various sources of waste from a production process of one of the livestock waste. The waste can come from slaughterhouses, livestock production, and the results of livestock business activities. This waste can be solid, liquid, and gas which, if not handled properly, will have adverse impact on the environment [7].

Waste is the waste material from a process of activity which still has economic value. Waste is now a problem for the community because the very stinging smell of waste is very disturbing. Waste in the field of animal husbandry such as feces, urine, skin, nails, and viscera. This waste still has nutrients that can be used in the process of making liquid fertilizer, compost, and biogas. The process of processing livestock waste into liquid fertilizer, compost and biogas can reduce waste that becomes a problem in the community. Of the many livestock wastes, the public perception of the processing of feces of beef cattle must be known.

\section{Research Method:}

The research was conducted in March 2018 until April 2018. This research was conducted in Patampanua Village, Marioriawa Subdistrict, Soppeng Regency. The type of research used is descriptive quantitative research type that is the kind of researches that explain or describe a research phenomenon as it is or discuss a variable without seeing the relationship between one variable with another variable. This research uses survey method. Survey method is used to know the knowledge and skills of farmers in making solid fertilizer from cow feces. The type of data used in this study is qualitative data is data expressed in the form of words, sentences and images and quantitative data. Data sources are primary data is data sourced from direct interviews with the breeders by using questionnaires such as identity data respondents, and responses respondent to research variable and secondary data is data obtained from related institutions. The population in this research is the whole breeder of beef cattle in Patampanua Village, MarioriawaSubdistrict, Soppeng Regency. The number of population in this research is 78 breeders of beef cattle and all population taken as sample of research. The data collection techniques used in this study is observation and interview. Data analysis used in this research is descriptive statistic. By using grouping model, simplification, and presentation like frequency distribution table and measurement by using likert scale. According to[8]Likert scale used to measure attitude, opinion, and perception of a person or group about social events or phenomenon. 
Citation: Sitti Nurani Sirajuddin, Ikrar Moh.Saleh, Jamilah Mustabi and Syamsinar Syukur, 2018. Perceptive Farmers Viewed from Knowledge and Skills in Utilizing Beef cattleFeces into Organic Solid Fertilizer. Advances in Environmental Biology, 12(5): 17-20

\section{RESULT AND DISCUSSION}

Characteristics of Respondents:

Characteristics of farmers greatly affect in the management of livestock business that is age, education level, the number of family members, business scale and long breeding [9]. Classification of respondents by age level in Patampanua village can be seen in Table 1.

Table 1: Characteristics of respondents in sub district Patampanua, District Marioriawa, Soppeng Regency.

\begin{tabular}{|c|c|c|c|}
\hline Characteristics & Description & Amount & Percentage \\
\hline \multirow[t]{3}{*}{ Age(years) } & $0-14$ & 0 & 0 \\
\hline & $15-64$ & 70 & 89,7 \\
\hline & 65 & 8 & 10,3 \\
\hline \multirow[t]{5}{*}{ Level of education } & College & 1 & 1,3 \\
\hline & SMA & 15 & 19,2 \\
\hline & SMP & 17 & 21,8 \\
\hline & SD & 40 & 51,3 \\
\hline & Not school & 5 & 6,4 \\
\hline \multirow[t]{3}{*}{ Number of family members (people) } & $1-3$ & 7 & 8,9 \\
\hline & $3-4$ & 58 & 74,4 \\
\hline & $5-6$ & 13 & 16,7 \\
\hline \multirow[t]{3}{*}{ Total livestock ownership(tail) } & $1-8$ & 71 & 91 \\
\hline & $9-16$ & 6 & 7,7 \\
\hline & $17-25$ & 1 & 1,3 \\
\hline \multirow[t]{3}{*}{ Breeding experience(year) } & $1-10$ & 57 & 73,1 \\
\hline & $11-33$ & 21 & 26,9 \\
\hline & $34-50$ & 0 & 0 \\
\hline
\end{tabular}

Source: Primaryof Data, 2018

Table 1 shows respondents in Patampanua Village, Marioriawa District, Soppeng District, aged 15-64, 70 farmers with percentage of 89.7\% and 8 farmers aged $>65$ with a percentage of $10.3 \%$. Productive age starts from the age of 15 to 60 years. These conditions support the livestock business that is run because it requires good physical skills so as to maximize in developing the farm business. This is in accordance with the opinion [10]that the ability of a breeder's work is strongly influenced by the age level. The more productive the breeder's age the more enthusiastic the new things are not yet known. In addition, age also affects the physical condition and motivation of farmers. This is according to the research of [11] that the non-productive age is at the age of 0-14 years, productive age 15-64 years old and 65 years old and above. The higher the age of a person then he is more likely to think more mature and act more wisely. Physically will affect the productivity of livestock business, where the higher the age of breeders, the ability to work relative decline. Added opinion[12]that the increasing age tends to increase knowledge, experience and skills of farmers.

In Table 1 shows that education level in Patampanua Village, Marioriawa Subdistrict of Soppeng Regency is still low. This is evidenced by respondents who do not go to school $6.4 \%$ and elementary school $51.3 \%$ and junior high $21.8 \%$. The rest at the level of higher education ie high school by $19.2 \%$, and $\mathrm{S} 1 \mathrm{by} 1.3 \%$. Most of the low-educated breeders, they still consider that their livestock business does not need education so it will be easier in receiving a technology. The level of education breeders tend to influence the way of thinking and the acceptance rate of innovation and new technology

The number of family dependents of the respondents in the village of Patampanua, Marioriawa District, Soppeng District, the largest number of family dependents is $2-5$ people amounted to $74.4 \%$. The number of dependents of the family is one of the factors that influence the farmers in taking decisions to adopt a technology. This is in accordance with the opinion of [13]that some things that have influence on technology, namely the number of dependents of the family, with the influence of disseminated technology is expected to increase farmers' income.

In Table 1 shows that most respondents have the number of beef cattle are respondents who have beef cattle with a scale of $1-8$ ie 71 people or $91 \%$. This is the number of livestock ownership that is still lacking, so most of the respondents have not done the cattle manure waste processing. This is in the opinion of [14] that more than $90 \%$ of smallholder farms characterized by such a relatively small scale business, ranging from 1-8 are traditional household and maintenance businesses that have not yet treated the waste generated from their livestock.

Table 1 shows that as many as $73.1 \%$ of respondents who have a long breeding experience of $1-10$ years, while as many as $26.9 \%$ of respondents who have experience breeding for 11-33 years. Breeders who have a long breeding experience generally have more knowledge than farmers who have just pursue farming. Breeding / farming experience becomes one measure of a person's ability to manage a farm. This is in accordance with the opinion of [15] that the experience of rising is an important capital for the success of a livestock farming activities. Different level of experience of each farmer will be different in their mindset in applying innovation in their farming activities. Application of technology and good management will influence the behavior of farmers trying to do their farm business. The longer a person's breeding experience, the skills possessed will be higher and better quality. It is also in the opinion of [16] that the more experience, the lessons learned, from the experience gained by the breeder can receive new technological innovations with various considerations.

Perceptive Breeders Viewed from Knowledge and Skills in Utilizing Beef Feces into Organic Solid Fertilizer:

Compost is a kind of natural fertilizer made by decomposing or decomposing organic materials of harvest remnants (straw, corn stalk, and other crop residues) as well as garbage mixed with manure and phosphate fertilizer as needed so as to ripen and into a material having a lower $\mathrm{C} / \mathrm{N}$ ratio. Compost that has been cooked has a character feels cold when touched, easily brittle if squeezed, odorless, and dark brown to blackish.

\section{A. Knowledge:}

Knowledge is an individual motivation to learn more about solid organic fertilizer technology so that breeders will be easier to adopt. But according to [17] that with the lack of information that people get is an obstacle in adopting. Knowledge can increase opportunities in an innovation so individuals must have the knowledge to use a technological innovation. The perception of beef cattle breeder in utilizing cow feces into solid organic fertilizer in terms of aspects of knowledge in the village of Patampanua can be seen in Table 2

Based on Table 2 shows that the perception of farmers in solid fertilizer processing is viewed from the aspect of knowledge in the village of Patampanua, the average weight of farmers' barriers as much as 156 or $66 \%$. Based on this amount can be said that most respondents have various responses. In the first indicator there are 73 farmers who choose to agree, there are 1 farmer choose less agree, and 4 farmers who choose not agree that they know about compost. This is in accordance with the opinion of [18] that knowledge of breeders obtained from the communication by obtaining information from other breeders to know the existing technology

The second indicator shows that as many as 35 farmers agree, as many as 6 farmers are less agree and as many as 37 breeders who do not agree that the breeders in the research location there are those who already know about the type and materials but there is not knowing so there are breeders who adopt and who have not adopted, this because there is no solid processing technology of organic fertilizer in the village of Patampanua. This is in accordance with the opinion of [19] that the utilization of cattle dung into fertilizer is still very limited to the needs of members of livestock farmer groups, production equipment and materials in the manufacture of organic fertilizer is still limited. 
Table 2: Perception of Cattle Breeders from the Knowledge Aspect in Patampanua Village.

\begin{tabular}{|c|c|c|c|c|}
\hline No. & Measurement indicators & Score & Frequency & Weight \\
\hline 1 & $\begin{array}{l}\text { breeders know about compost } \\
\text { agree } \\
\text { less agree } \\
\text { not agree }\end{array}$ & $\begin{array}{l}3 \\
2 \\
1\end{array}$ & $\begin{array}{l}73 \\
1 \\
4\end{array}$ & $\begin{array}{l}219 \\
2 \\
4\end{array}$ \\
\hline \multicolumn{3}{|c|}{ Amount } & 78 & 225 \\
\hline 2 & $\begin{array}{l}\text { Breeders know the types and materials in composting } \\
\text { agree } \\
\text { less agree } \\
\text { not agree }\end{array}$ & $\begin{array}{l}3 \\
2 \\
1\end{array}$ & \begin{tabular}{|l}
35 \\
6 \\
37 \\
\end{tabular} & \begin{tabular}{|l}
105 \\
12 \\
37 \\
\end{tabular} \\
\hline \multicolumn{3}{|c|}{ Amount } & 78 & 154 \\
\hline 3 & $\begin{array}{l}\text { Farmers know the processing of livestock waste into compost } \\
\text { Agree } \\
\text { Less agree } \\
\text { Not agree }\end{array}$ & $\begin{array}{l}3 \\
2 \\
1\end{array}$ & $\begin{array}{l}4 \\
5 \\
69\end{array}$ & $\begin{array}{l}12 \\
10 \\
69\end{array}$ \\
\hline \multicolumn{3}{|c|}{ Amount } & 78 & 91 \\
\hline \multicolumn{3}{|c|}{ Average of weight } & & 156 \\
\hline
\end{tabular}

Source: Primary of data, 2018.

The third indicator is knowledge of livestock farmers in cattle waste processing as much as 4 farmers agrees, as many as 5 farmers less agrees, and as many as 69 breeders disagree. Based on the results of research respondents that the knowledge of farmers is still less in the processing of cattle manure waste into compost. This is due to have a low level of education and less livestock farming experience in livestock.The limited knowledge of farmers in processing waste so that cannot be developed, both in processing of biogas and processing of organic fertilizer.

B. Skills:

Skill is the respondent's action towards the manufacture of organic fertilizer technology solid. While perception of farmers on the manufacture of organic fertilizer cattle farmers in terms of skills aspects in the village of Patampanua can be seen in Table 3

Table 3: Perception of Beef Cattle Breeders from the Aspects of Skills in the Village Patampanua.

\begin{tabular}{|c|c|c|c|c|}
\hline No. & Measurement indicators & Score & Frequency & Weight \\
\hline 1 & $\begin{array}{l}\text { Farmers apply waste treatment technology to solid organic } \\
\text { fertilizer } \\
\text { agree } \\
\text { less agree } \\
\text { not agree }\end{array}$ & $\begin{array}{l}3 \\
2 \\
1\end{array}$ & $\begin{array}{l}20 \\
30 \\
28\end{array}$ & $\begin{array}{l}60 \\
60 \\
28\end{array}$ \\
\hline \multicolumn{3}{|c|}{ Amount } & 78 & 148 \\
\hline 2 & $\begin{array}{l}\text { Farmers utilize waste processing technology into solid organic } \\
\text { fertilizer } \\
\text { agree } \\
\text { less agree } \\
\text { not agree }\end{array}$ & $\begin{array}{l}3 \\
2 \\
1 \\
\end{array}$ & $\begin{array}{l}20 \\
30 \\
28 \\
\end{array}$ & $\begin{array}{l}60 \\
60 \\
28 \\
\end{array}$ \\
\hline \multicolumn{3}{|c|}{ Amount } & 78 & 148 \\
\hline 3 & $\begin{array}{l}\text { Farmers conduct organic fertilizer waste processing according } \\
\text { to procedure } \\
\text { agree } \\
\text { less agree } \\
\text { not agree }\end{array}$ & $\begin{array}{l}3 \\
2 \\
1\end{array}$ & $\begin{array}{l}4 \\
62 \\
12\end{array}$ & $\begin{array}{l}12 \\
124 \\
12\end{array}$ \\
\hline \multicolumn{3}{|c|}{ Amount } & 78 & 148 \\
\hline \multicolumn{3}{|c|}{ Average of amount } & & 148 \\
\hline
\end{tabular}

Source: Primary data, 2018.

Based on Table 3 shows that the perception of farmers on the manufacture of solid organic fertilizer on skill aspects in the village of Patampanua, average weight of farmers' perception as much as 148 or $63 \%$. Based on the amount obtained by farmers apply and utilize waste processing technology into solid organic fertilizer as much as 20 farmers who agree, there are 30 breeders who are less agree, and there are 28 breeders who disagree. Farmers conduct organic fertilizer processing according to procedure as much as 4 farmers agrees, there are 62 farmers less agrees, and there are 12 breeders disagree. This shows that farmers have not optimally utilized livestock manure for organic fertilizer because the farmers do not know that the materials or biomass around them with abundant amounts can be processed in addition to family income. Based on the results of the research most of the farmers believe that if breeders do not process according to the procedure can grow weeds (plant pest) when organic fertilizer is used, this is in accordance with the opinion [20] that livestock waste is a byproduct of livestock business that can be made as the main source of organic fertilizer by using a simple manufacturing method. It is also in accordance with the opinion of [21]that turning animal manure into organic fertilizer is quite easy, but if it is not handled properly it will cause environmental pollution and nutrient depletion so it takes effort to handle it.

\section{Conclusion:}

Farmers are less aware of the types and materials and processing of organic fertilizer and not yet skilled in the utilization of organic fertilizer so it needs to be done counseling and training routinely in processing cow feces into solid fertilizer (compost)

\section{ACKNOWLEDGMENT}

Thanks to the Ministry of Technology and Higher Education which has provided opportunities to Activities of regional partnership program (PKW)

\section{REFERENCES}

[1] Tanri Giling Rasyid, S.T. Rohani, Muhammad Aminawar, Muhammad Darwis, 2018. The Level of Social Capital and Its Effect on The Participation of Farmers on Goat Livestock Business Development In Jeneponto Regency South Sulawesi Province-Indonesia.Advances in Environmental Biology, 12(2): 13 DOI: $10.22587 / \mathrm{aeb} .2018 .12 .2 .1$. 
[2] Agustina Abdullah, Jamila, A. Amrawati, St Nurlaela, A. Amrullah, 2017. Analysis of the Determining Factors on the Performance of Extension Officers For The Transfer of Livestock Feed Technology. American-Eurasian Journal of Sustainable Agriculture, 11(5): $72-76$.

[3] Sitti Nurani Sirajuddin, Hastang, St.rohani, M. Erik Kurniawan, 2016. Level Technology Adoption and Characteristic Cattle Breeders who following Bachelor Village Building. American-Eurasian Journal of Sustainable agriculture, 10(5): 28-32.

[4] Sitti Nurani Sirajuddin, Ahmad Ramadhan Siregar, Palmarudi Mappigau, 2017. Adoption Rate of Beef Breeders Technology Following Partnership System in Barru Regency. American-Eurasian Journal of Sustainable Agriculture, 11(6): 31-34.

[5] Imran, M., 2013. Persepsi masyarakat terhadap pelaksanaan perda no. 12 tahun 2010 oleh UD. Rahma Di Kecamatan Bantimurung Kabupaten Maros. Skripsi. Fakultas Peternakan. Universitas Hasanuddin. Makassar.

[6] Setiawan, B.S., 2010. Membuat Pupuk Kandang Secara Cepat. Tim Penulis ETOSA IPB, Penebar Swadaya, Jakarta.

[7] Adityawarman, C.A. Salundik, A. Lucia, 2015. Pengolahanlimbah ternak secara sederhana Di Desa Patalassang Kabupaten Sinjai Sulawesi Selatan. Jurnal Teknologi Hasil Ternak. Fakultas Peternakan. IPB. Bogor, 3(3): 171-177.

[8] Riduwan, 2007. Skala Pengukuran Variabel-Variabel Penelitian. Penerbit Alfabeta. Bandung.

[9] Sitti Nurani Sirajuddin, Aslina Asnawi, Sutomo Syawal, M. Jamal, 2016. Response of Cattle Breeders Silage in Soppeng Regency, South Sulawesi Province. American-Eurasian Journal of Sustainable Agriculture, 10(3): 33-36.

[10] Sumiati, 2011. Analisiskelayakanfinansialdanfaktor-faktor yang memotivasipetanidalamkegiatan agroforestry. Tesis. Institut Pertanian Bogor.

[11] Kasim, K., N. Dan Sirajuddin, 2008. Peranan Usaha Wanita PeternakItik Terhadap Pendapatan Keluarga (Studi Kasus di Kelurahan Manisa Kecamatan Baranti Kabupaten Sidrap). Fakultas Peternakan Universitas Hasanuddin, Makassar.

[12] Eddy, B.T., W. Roessali, S. Dan Marzuki, 2012. Dairy cattle famers' behavior And factors affecting the effort to enhanche The economic of scale at Getasan District Semarang Regency. J. Indonesian Trop. Anim. Agric., 37: 34-40.

[13] Azizi, A., Z. Nasution, 2008. Adopsiteknologibudidayaikankerapusistemkerambajaringapung. Badan Riset Kelautandan Perikanan. Jakarta.

[14] Rasali, H., Matondangdan S. Rusdiana, 2013. Langkah-Langkah Strategisdalam Mencapai Swasembada Daging Sapi/Kerbau 2014. Pusat Penelitiandan Pengembangan Peternakan Departemen Pertanian. Bogor.

[15] Hendrayani, 2009. Analisis Faktor-Faktor yang Mempengaruhi Motivasi Berternak Sapi di Desa Koro Benai Kec. Benai Kap. Kuantan Singingi. Jurnal Peternakan, 6(2): 53-62.

[16] Herawati, T., A. Anggraeni, L. Praharani, D. Utami, dan A. Argiris, 2012. Peran inseminator dalamkeberhasilaninseminasibuatanpadasapiperah. Jurnal Informatika Pertanian, 21(2): 81-88.

[17] Rogers, E.M., 2003. Diffusions of Innovations, Third Edition. Free Press. New York.

[18] Witjaksono, R., 2000. Hubunganperilakukomunikasidantingkatpemahamaninformasianggotakelompoktanitentangpaketteknologi supra insus di WKBPP Sanden, Kabupaten Bantul, D.I. Yogyakarta. Fakultas Pascasarjana IPB. Bogor.

[19] Huda, S. dan W. Wikanta, 2016. Pemanfaatan limbah kotoran sapi menjadi pupuk organik sebagai upaya mendukung usaha peternakan sapi potong di Kelompok Tani Ternak Mandiri Jaya Desa Moropelang Kec. Babat Kab.Lamongan. Axiologiya. Jurnal Pengabdian Masyarakat. Surabaya, 1: 23-31.

[20] Maksudi, S. Wigati, dan E. Wiyanto, 2015. Produksipupukorganikpadatdancairdari sludge biogas dan bio-urin. Jurnal Pengabdian Masyarakat. Fakultas Peternakan. Universitas Jambi., 30(1): 73-80.

[21] Setiawan, S., T.B. Benito, A.H. Yuli, 2013. Pengolahan limbah ternak pada pengelolahan ternak sapi potong Di Kabupaten Majalengka. Jurnal Ilmu Ternak. Fakultas Peternakan. Universitas Padjajaran, 13(1): 24-30. 